ART SUBJECTS 



\section{ART SUBJECTS}

MAKING ARTISTS

IN THE AMERICAN

UNIVERSITY

Howard Singerman

UNIVERSITY OF CALIFORNIA PRESS

Berkeley Los Angeles London 
University of California Press

Berkeley and Los Angeles, California

University of California Press, Ltd.

London, England

(C) 1999 by

The Regents of the University of California

Library of Congress Cataloging-in-Publication Data

Singerman, Howard.

Art subjects : making artists in the American university / Howard Singerman.

p. $\mathrm{cm}$.

Includes bibliographical references and index.

ISBN-13: 978-0-520-21502-3 (alk. paper).-ISBN 0-520-21502-8 (alk. paper)

1. Art-Study and teaching (Graduate)-United States.

2. Universities and colleges--United States-Graduate work.

I. Title.

N346.A1S56 1999

$707^{\prime} .1^{\prime} 173-\mathrm{dc} 21$

$98-41460$

Printed in the United States of America

$08 \quad 07 \quad 06$

$\begin{array}{lllll}9 & 8 & 7 & 6 & 5\end{array}$

The paper used in this publication meets the minimum requirements of ANSI/NISO Z39.48-1992

(R 1997) (Permanence of Paper). () 
To my mother, and in memory of my father 
